\title{
SOS1 wt Allele
}

National Cancer Institute

\section{Source}

National Cancer Institute. SOS1 wt Allele. NCI Thesaurus. Code C116309.

Human SOS1 wild-type allele is located in the vicinity of 2 p21 and is approximately $143 \mathrm{~kb}$ in length. This allele, which encodes son of sevenless homolog 1 protein, plays a role in both signaling and guanine nucleotide exchange. Mutation of the gene is associated with both gingival fibromatosis type 1 and Noonan syndrome type 4 . 